\title{
Behaviour, Lockdown and the Natural World
}

Dandy, Norman

\section{Environmental Values}

DOI:

$10.3197 / 096327120 \times 15868540131215$

Published: 01/06/2020

Publisher's PDF, also known as Version of record

Cyswllt i'r cyhoeddiad / Link to publication

Dyfyniad o'r fersiwn a gyhoeddwyd / Citation for published version (APA):

Dandy, N. (2020). Behaviour, Lockdown and the Natural World. Environmental Values, 29(3), 253-259. https://doi.org/10.3197/096327120X15868540131215

\footnotetext{
Hawliau Cyffredinol / General rights

Copyright and moral rights for the publications made accessible in the public portal are retained by the authors and/or other copyright owners and it is a condition of accessing publications that users recognise and abide by the legal requirements associated with these rights.

- Users may download and print one copy of any publication from the public portal for the purpose of private study or research.

- You may not further distribute the material or use it for any profit-making activity or commercial gain

- You may freely distribute the URL identifying the publication in the public portal ?
}

Take down policy

If you believe that this document breaches copyright please contact us providing details, and we will remove access to the work immediately and investigate your claim. 


\section{Behaviour, Lockdown and the Natural World}

Lockdown. Social distance. It sounds, in many ways, like the ideal conditions in which to write! The world shrinks, and with it so should the opportunities for distraction, disturbance or other forms of social interaction that might draw us away from the task at hand. After all, surely these conditions are precisely what 'writers' retreats' deliver? I used to write a great deal in my garden shed, seeking distance from colleagues, friends and family responsibilities alike so as to focus and concentrate.

The 'lockdown' under which many of us find ourselves whilst I write this editorial is different, although not entirely unfamiliar. Some of my behaviours have changed, others have not. The main differences from my usual everyday life are the location of my behaviours - at home rather than the workplace and the knowledge that there are many millions of humans beyond my shrunk world whose lives are different. We have lost loved ones and colleagues, and many have lost jobs. Others are working furiously to help and heal many more people than they would usually be helping and healing. However, for me things are not so bad, I can still walk across fields and down country lanes with my family (albeit only once per day) - we just have to cross the road if we encounter other humans. I can still visit a supermarket - I just have to wait for others to choose their cucumber or olives before I step forward to choose mine. I can still work (and write!) - I just have to learn how to join virtual meetings using whichever of the apparently infinite variety of software my colleague or co-worker prefers.

The current global health crisis is, amongst many other things, a moment that affords extraordinary insight into and reflection on human behaviour. From 'panic buying' and bizarre arson attacks on telecommunication masts, to acts of neighbourly kindness and mass volunteerism, we are observing numerous atypical behavioural phenomena. Within this, as increasingly noted by journalists and scientists, are a number of dimensions with substantial implications for the natural world.

Perhaps most striking is the fact that governments across the globe have overseen behaviour change on an extraordinary scale and at an unbelievable rate. In just a few weeks the everyday movements, routines and habits of billions of humans across the globe have been brought to a halt. It seems that anything is possible. Of course, the extent to which governments have led this change, and how much they have simply been catching up with and facilitating change demanded by the agency of others (human and non-human), will keep political analysts busy for many years. A minority have not heeded government advice - continuing to behave as before - and indeed some political leaders have resisted calling for behavioural change. However, the fact remains that, in response to this particular threat, the actions of many, many millions of people have changed - rapidly. 


\section{EDITORIAL}

Science has played an incredibly prominent role in steering the course of government responses - with politicians flanked by scientific advisors and medical officers repeating assertions of being 'science-led'. We have, unsurprisingly, witnessed the science steering different politicians in different directions, being acted upon differently for different motives and ends. Our biological, genetic and epidemiological understanding of the new virus is, of course, emergent and uncertainty has permeated responses throughout the crisis.

The huge changes in human behaviour have, predictably, resulted in substantial environmental benefits with, for example, large drops in air pollution ${ }^{1}$ and noise disturbance ${ }^{2}$. This is particularly apparent across the globe's most affected urban and industrial areas with behaviours such as commuting and recreation drastically reduced. Furthermore, media channels are replete with stories of wildlife 'reclaiming' urban spaces currently void of human life, be it marine life in Venice ${ }^{3}$, boar in Bergamo and jaguars in Tulum ${ }^{4}$, or closer to home for me, goats in Llandudno, North Wales ${ }^{5}$. Even plant species are capitalising on the opportunity with wild flowers thriving as grass cutting in public spaces is halted ${ }^{6}$ ! Regardless of the accuracy of these stories and the precise relationships between human behaviour and these phenomena, they serve to simultaneously substantiate the arguments made by many environmentalists and further mythologise (and to a certain extent, eulogise) the dichotomy between 'humans' and 'nature' in the public imagination.

Entangled with these numerous claims relating to problematic human behaviour and environmental benefit has been the emergence of a more fundamental sense that the current crisis reflects a more profound environmental dis-ease: that all is not well with the relationship between us and the natural world. A particular theme of this has been the exploitation of non-human animals that appears to be the epicentre of the current crisis ${ }^{7}$. This sentiment has perhaps been most concisely captured by documentary-maker Louis Theroux's April Fool's Day tweet 'So this is all because someone ate a pangolin?'. Whether genetic analysis shows it is indeed the pangolin, bats, or another wild

1. https://www.theguardian.com/environment/2020/mar/23/ coronavirus-pandemic-leading-to-huge-drop-in-air-pollution

2. https://www.theatlantic.com/science/archive/2020/04/ coronavirus-pandemic-earth-pollution-noise/609316/

3. https://www.theguardian.com/environment/2020/mar/20/ nature-is-taking-back-venice-wildlife-returns-to-tourist-free-city

4. https://www.telegraph.co.uk/travel/news/wild-animals-coronavirus-nature-reclaims-resorts/

5. https://www.nytimes.com/2020/04/01/science/coronavirus-animals-wildlife-goats.html

6. https://www.bbc.co.uk/news/science-environment-52215273

7. https://www.theguardian.com/world/2020/apr/06/ban-live-animal-markets-pandemics-unbiodiversity-chief-age-of-extinction; https://www.washingtonpost.com/science/2020/04/03/ coronavirus-wildlife-environment/ 
species that was the source of the current pandemic ${ }^{8}$ will eventually be largely irrelevant to all but food hygiene authorities and scientists. What Theroux is bringing into view is the all too arbitrary and mundane practice of human consumption of wild animals, along with the myriad hunting, transport, trading and preparation behaviours involved.

Human behaviours, their causes, and their relationships with the environment is the central theme of this issue of our journal. Starting at the global level, Hui-Ju Kuo and Yang-Chih Fu seek to add to our understanding of how environmental attitudes vary across nations, and how these relate to pro-environmental behaviours. Drawing data from thirty two countries, the authors investigate the covariance of three broad types of environmental attitudes (willingness to sacrifice; biospheric orientation; environmental scepticism) and pro-environmental behaviours including recycling, reduced driving and lowering energy use. The analysis reveals clear regional and national variation in attitudes, alongside converging levels of pro-environmental behaviour. Recycling proves to be the most popular behaviour in nearly all countries within the study, with reductions in driving being least common. Within a subset of sixteen countries where the data allowed, strong positive interactions are found between attitudes and behaviours. The authors state: 'When respondents expressed higher levels of moral obligation and/or were more willing to sacrifice themselves to protect the environment, they were more likely to engage in recycling, cut back on driving, reduce energy use, save water or avoid buying certain products for environmental reasons'. We can therefore take heart from the knowledge that work being done to clarify and proliferate moral obligations towards the natural world is clearly having a positive effect.

Michael Vincent and Ann-Kathrin Koessler shift our focus to the microlevel of the individual. In a predominantly methodological reflection, they explore the conceptual terrain of 'moral spillovers' and their relation to proenvironmental behaviours. Moral spillovers are characterised as a kind of psychological moral accounting between behaviours, where our prior moral deficit (or surplus) can lead to a balancing out with subsequent moral surplus (or deficit), or indeed where initial behaviours set a trend. The authors provide resources and guidance for researchers in this subject area, and make a plea for moral psychologists to take greater care in their reflection on and categorisation of studied moral actions. In particular they advocate better delineating of morality, more effectively distinguishing domains of interest from domains of action, and ensuring researchers values do not pre-determine or prejudice judgements of morality.

Chelsea Batavia and co-authors begin their engagement with pro-environmental behaviours with the proposition that environmental ethicists have done little to consider whether individual uptake or adoption of environmental ethical positions actually influences observed human behaviour. This will cause

8. https://www.nature.com/articles/d41586-020-00548-w 


\section{EDITORIAL}

many readers of this journal to pause for thought as it signals assumptions regarding who is given the label of 'environmental ethicist', what style of inquiry they undertake (e.g. what constitutes 'consideration' of empirical change), and what is the target of those inquiries? There is, of course, a very substantial literature investigating the behavioural influence of stated environmental values within the pages of this journal (e.g. Braito et al 2017, Howell and Allen 2017, Lundberg et al 2019) and others. Indeed, as noted above, within this issue Kuo and $\mathrm{Fu}$ demonstrate the positive relationship between biospheric concerns and pro-environmental attitudes and behaviours. Do these studies fall outside of environmental ethics? Furthermore, this position stimulates consideration of what should be considered as the objective of environmental ethics. The psychological limits of individuals that constrains the ability to 'grasp' environmental issues such as climate change has in fact led to calls for ethicists to focus on policy change rather than on changing individual behaviours (e.g. Kasperbauer 2016).

The paper from Batavia and co-authors explores this subject area by mapping the potential synergies and commonalities between the psychological literature and three prominent positions in environmental philosophy: the intrinsic value of nature, an ecofeminist ethic of care, and Leopold's land ethic. These three positions can implicate relatively strong ethical commitments to the natural world. Consequently, environmental ethicists may indeed presume more noticeable pro-environment behaviour to flow from these relative to that generated by more orthodox 'shallower' green ethics such as sustainability focused on future human generations - which does not receive attention in the paper. Whilst the authors identify a range of potentially relevant contributions from the psychology literature, their conclusion regarding a link between these ethical positions and pro-environmental behaviours is a relatively circumspect 'perhaps'.

At the heart of the challenge here is the dichotomy drawn between the individual - the psychologist's primary unit of analysis - and their socio-economic structure and context. As the authors state in their conclusion 'the larger context ... conditions and constrains patterns of thought, feeling, and behaviour'. To what extent is it useful to interrogate the 'decisions' of individuals and their specific ethical allegiances when their everyday context is shaped so fiercely as to nullify so many possible 'choices'? The authors call for greater dialogue between psychologists and philosophers, to which we might also add sociologists, anthropologists and others.

Fiona Shirani and co-authors provide an excellent counterpoint to the above with their paper exploring the sustainability-related possibilities and opportunities available within a radically different everyday context: the Lammas Tir y Gafel 'ecovillage' in Wales, UK. Here, lifestyles are 'quite distinct from mainstream ways of living, with environmental consciousness at the forefront of everyday life'. Prior study of the ecovillage movement has unpacked this 
distinctiveness, showing it to be centred around close contact with and experience of nature. The natural environment becomes an active agent in such settings with a consequent and gradual lessening of human individuality and voice (Brombin 2019). This surely has implications for the study of the behaviour of individuals. At the core of the distinctiveness for Shirani and co-authors is the principle of self-sufficiency, and the paper reports interviews with village residents subsequent to successfully obtaining planning permission within which was an explicit target to meet 'at least $75 \%$ of household needs from the land'.

The authors highlight a blend of bureaucratic (official) success with personal ambivalence in relation to some challenges of village life, including the long-term absence of family living space within the self-build houses. Of particular note, however, is the importance amongst residents of having had a clear impact - on policy and behaviour - beyond the boundaries of the village. The research reveals the extent to which perceptions of 'success' in this case have become entangled with being pioneers of low-impact living - generating policy adaptation and enabling others to follow their example. Usefully the authors make use of Dobson's longstanding distinction between a reformist 'environmentalism' and the more radical 'ecologism'. This can in fact help us make sense of the contrast between the 'pro-environmental behaviours' of the papers discussed above and more profound 'alternative ways of living' such as the self-build localism of the 'ecovillage'.

Kenneth Pike and C. Tyler Desroches take us even further along the route towards alternative lifestyles in an engaging essay on the potential held by virtual consumption in the quest for sustainability. Virtual consumption is characterised as the replication of 'authentic' consumptive experiences by alternative means - a 'high-fidelity walkthrough of the Louvre' instead of a carbon-fuelled visit to the gallery itself, for example. The authors explore these 'consumptive' experiences in some detail noting, for example, that the objection that a virtual tour of the Louvre isn't authentically the Louvre, is akin to claiming that 'talking to someone on the phone isn't really talking to a person'. The authors also effectively engage with Nozick's objections to virtual experiences characterised by his 'experience machine' thought experiment. Nozick's argument was that the very fact of an experience being virtual would necessarily leave an individual worse off. Pike and Desroches, however, resituate this critique in the contemporary world of virtual experiences which Nozick would have been unlikely to be able to foresee, and identify instances where virtual reality may now actually exceed the capabilities of 'reality' to provide positive experiences and increase well-being.

A number of examples are drawn on to convincingly illustrate the potential sustainability gains that could be made with the adoption of virtual consumption behaviours - substituting material exchanges for information exchanges. If these experiences are available it may facilitate the satisfaction of consumer 


\section{EDITORIAL}

desires whilst greatly reducing the unsustainable material consumption intrinsic to the travel and production practices required for 'real' consumption. One might equally ask, however, whether the availability of such virtual resources may increase demand for the authentic experience, hence growing the environmental impact. Is not the current goal of image-based 'virtual' experiences of stunning natural landscapes (e.g. tourist authority videos) actually convincing people that they should in fact visit? The authors are alive to elements of this critique, acknowledging that even virtual consumption must be underpinned by material goods and production. Consequently they identify the need for appropriate analyses of virtualisation to investigate whether they are in fact more sustainable than the authentic experience they replicate. There is also a vulnerability generated by the theorised availability of high-fidelity virtual experiences - the potential threat it may create to the authentic material on which the original experience is based. This brings to mind a story many years ago in the spoof newspaper The Onion, in which the National Parks of North America were shifted online so as to, if my memory serves me correctly, make the 'real' space available for development! This, arguably, would not contribute to the achievement of sustainability goals.

The current global health crisis and the responses to it leave us asking many questions about our behaviour and its relationship to the natural world. The contributions to this issue of Environmental Values show that this is a very active area of contemporary scholarship. One of the earliest questions to be answered will be how long the observed changes will last. In the last few days some locations are beginning to loosen restrictions, and rumours of the postcrisis party are already circulating! Will the release from lockdown see a rapid reversion to pre-existing behaviours - perhaps even with an immediate glut of activity and consumption that could cancel out the unintended environmental gains? Or has the context changed beyond restoration? Might we have learnt new self-sufficiencies or novel practices of work and consumption that reduce our impact on the natural world? Once we have mastered the technology as we are now having to, what is there to stop us holding more virtual meetings, especially where our colleagues are located remotely from us? There is also likely to be much scholarly attention given to the distinct behavioural responses to 'pulse' disturbances - such as pandemics - and 'pressure' disturbances - such as climate change and biodiversity loss.

Perhaps the most vital question is whether, as a result of the current crisis, there will be any change in the values that underpin and guide human behaviours? In her recent acceptance message following election to the UK Labour Party's deputy leadership Angela Rayner MP said 'things have dramatically changed in our country in recent months but our values remain the same'. Is that what we should hope for as a consequence of such a traumatic global experience? Or can we hope for a more structural shift towards values that 


\title{
EDITORIAL
}

underpin novel 'alternative ways of living' that might secure a more sustainable future?

\author{
NORMAN DANDY \\ Bangor University
}

\section{REFERENCES}

Batavia, C., J.K. Bruskotter and N. Michael. 2020. 'Pathways from environmental ethics to pro-environmental behaviours? Insights from psychology'. Environmental Values 29 (3): 317-337.

Braito, M.T., K. Böck, C. Flint, A. Muhar, S. Muhar and M. Penker. 2017. 'Human-nature relationships and linkages to environmental behaviour'. Environmental Values 26 (3): 365-389.

Brombin, A. 2019. 'The ecovillage movement: New ways to experience nature'. Environmental Values 28 (2): 191-210.

Howell, R. and S. Allen. 2017. 'People and planet: Values, motivations and formative influences of individuals acting to mitigate climate change'. Environmental Values 26 (2): 131-155.

Kasperbauer, T.J. 2016. 'The implications of psychological limitations for the ethics of climate change'. Environmental Values 25 (3): 353-370.

Kuo, H-J. and Y-C. Fu. 2020. 'global convergence and national disparities in the structure of environmental attitudes and their linkage to pro-environmental behaviours'. Environmental Values 29 (3): 261-291.

Lundberg, P., A. Vainio, A. Ojala and A. Arponen. 2019. 'Materialism, Awareness of Environmental Consequences and Environmental Philanthropic Behaviour Among Potential Donors' Environmental Values, 28(6): 741-762.

Pike, K. and T. DesRoches. 2020. 'Virtual consumption, sustainability and human well-being'. Environmental Values 29 (3): 361-378.

Shirani, F., C. Groves, K. Henwood, N. Pidgeon and E. Roberts. 2020. 'What counts as success? Wider implications of achieving planning permission in a low-impact ecovillage'. Environmental Values 29 (3): 339-359.

Vincent, M. and A-K. Koessler. 2020. 'Mapping moral pluralism in behavioural spillovers: A cross-disciplinary account of the multiple ways in which we engage in moral valuing'. Environmental Values 29 (3): 293-315. 
